\title{
Fish diversity in nature reserves of Jiangxi Province, China
}

\author{
Chao Yin, Liangliang Huang, Li Xu, Jian Huang \& Minghui Gao
}

Keywords: freshwater fish, species diversity, nature reserves, Jiangxi Province

\section{Abstract}

According to the fish checklist of 14 nature reserves in Jiangxi Province, a total of 146 species of 7 orders, 26 families were present. Nature reserves of Cypriniformes were the major components of the fish fauna, consisting of 101 species, accounting for $69.28 \%$ of the total. Nature reserves of Siluriformes, consisting of 23 species, accounted for $15.75 \%$ of the total. For the family diversity (DF), Poyang Lake Nature Reserve scored the highest value (10.72), Ganjiangyuan Nature Reserve was the lowest at just 2.022. The genus diversity (DG) in Poyang Lake Nature Reserve, Nanjishan Nature Reserve, Wuyishan Nature Reserve, Jiulingshan Nature Reserve, Jinggangshan Nature Reserve, Jiulianshan Nature Reserve and Matoushan Nature Reserve are 3.746, 3.707, 3.391, 3.379, 3.355, 3.352 and 3.169 respectively. The result shows that the G-F index (DG-F) in Poyang Lake Nature Reserve is 0.651 . The DF-G in Ganjiangyuan Nature Reserve, Yunjushan Nature Reserve, Yangiifeng Nature Reserve, Lushan Nature Reserve was negative. The cluster analysis divides the 14 nature reserves into eight groups for their geographical positions and river types.

\section{Introduction}

Jiangxi Province, the whole area covering almost $166900 \mathrm{~km}^{2}$ (Figure 1), is located in the south of China and lies between $24^{\circ} 29^{\prime} 14^{\prime \prime}-30^{\circ} 04^{\prime} 41^{\prime \prime} \mathrm{N}$ and $113^{\circ} 34^{\prime \prime} 36^{\prime \prime}-118^{\circ} 28^{\prime} 58^{\prime \prime}$ E (Guo \& Liu 1995). The north is relatively flat while the other sides are surrounded by mountains. More than 2400 rivers have been discovered in Jiangxi province. The main rivers are Ganjiang River, Fuhe River, Xinjiang River, Xiuhe River and Raohe River, which flow into Poyang Lake. And Poyang Lake, the largest body of freshwater in China, is interlaced with five rivers to form a complete riverine-lacustrine network (Huang et al. 2013). Influenced by the subtropical monsoon, with a mild climate and plenty of rainfall, the annual rainfall in the area ranges from $1341 \mathrm{~mm}$ to $1940 \mathrm{~mm}$. Jinggangshan Nature Reserve (NR), the first national NR, was created in 1981, followed by Taohualing NR, Jiulianshan NR, Guanshan NR, Wuyishan NR in subsequent years. By 2012 there were almost 200 NRs of all levels and types, including 11 national NRs, 35 provincial NRs, 1 city-level NR and 153 countylevel NRs (Ministry of Environmental Protection of The PRC 2013). Ganjiangyuan NR, Guanshan NR, Jinggangshan NR, Jiulianshan NR, Jiulingshan NR, Lushan NR, Matoushan NR, Nanjishan NR, Poyang Lake NR, Qiyunshan NR, Wuyishan NR, Yangjifeng NR, Yihuang NR, and Qiyunshan NR were investigated on freshwater fish. Except for provincial NRs Yihuang NR and Yunjushan NR, all the others are national. Nanjishan NR and Poyang Lake NR are a type of wetland, Yihuang NR and Yangjifeng NR belong to wildlife reserves and the others are forest ecological reserves (Table 1).

With the five rivers and one lake, Jiangxi Province lays a good foundation for the fishery resources. According to the previous studies, more than 1000 species of freshwater fish have been found in China and
229 of them in Jiangxi Province (Huang \& Wu 2010a). Since the $20^{\text {th }}$ century, many researchers have investigated the fish fauna in this area. In 1938, 64 species were discovered in Jiangxi Province, 108 species in Poyang Lake belonged to 12 orders, 24 families, 72 genera (Guo et al. 1964; Jiang 1985). Surveys from 2007 to 2009 suggest that there are 136 fish species in Poyang Lake and 118 in Ganjiang River (Huang \& Gong 2007; Wu et al. 2009). Later, fish in the Fuhe River, Ganjiang River, northwest and northeast were investigated (Liu 1985; Zhang et al. 1996; Huang \& Wu 2010a; Chen et al. 2011). Despite the research into fish biodiversity and composition and a number of articles published, a comprehensive study has not yet been done of fish biodiversity in the NRs in Jiangxi Province. In order to understand the fish distribution of NRs systematically, it is necessary to make a comprehensive analysis on the spatial distribution and composition in NRs. The purpose of this study is to: (1) characterize the species composition of the fish fauna and distribution in 14 NRs. (2) analyse the biodiversity and relationship of fish in 14 NRs.

\section{Materials and methods}

A number of papers on the fish have studied them in the 14 NRs, a good opportunity to compile a list of fish species to discuss the biodiversity in the NRs of Jiangxi Province (Liu \& Fang 2001; Liu et al. 2002; Hu et al. 2005; Liu \& Fu 2006; Huang et al. 2008; Li et al 2008; Hu et al. 2009; Huang \& Wu 2010a, b; Guo et al. 2011; Hu et al. 2011; Zhou et al. 2013; Hu et al. 2014a,b; Yang et al. 2015).

G-F index was used to analyse the avian-mammalian species diversity, but now it is always used to study the fish diversity (Jiang \& Ji 1999; Li \& Wu 2006; Cai et al. 2009; Huang \& Liu 2011). Computing the diversity indexes at the genus level (G-index) and the family level (F-index); then to calculate the ratio of 


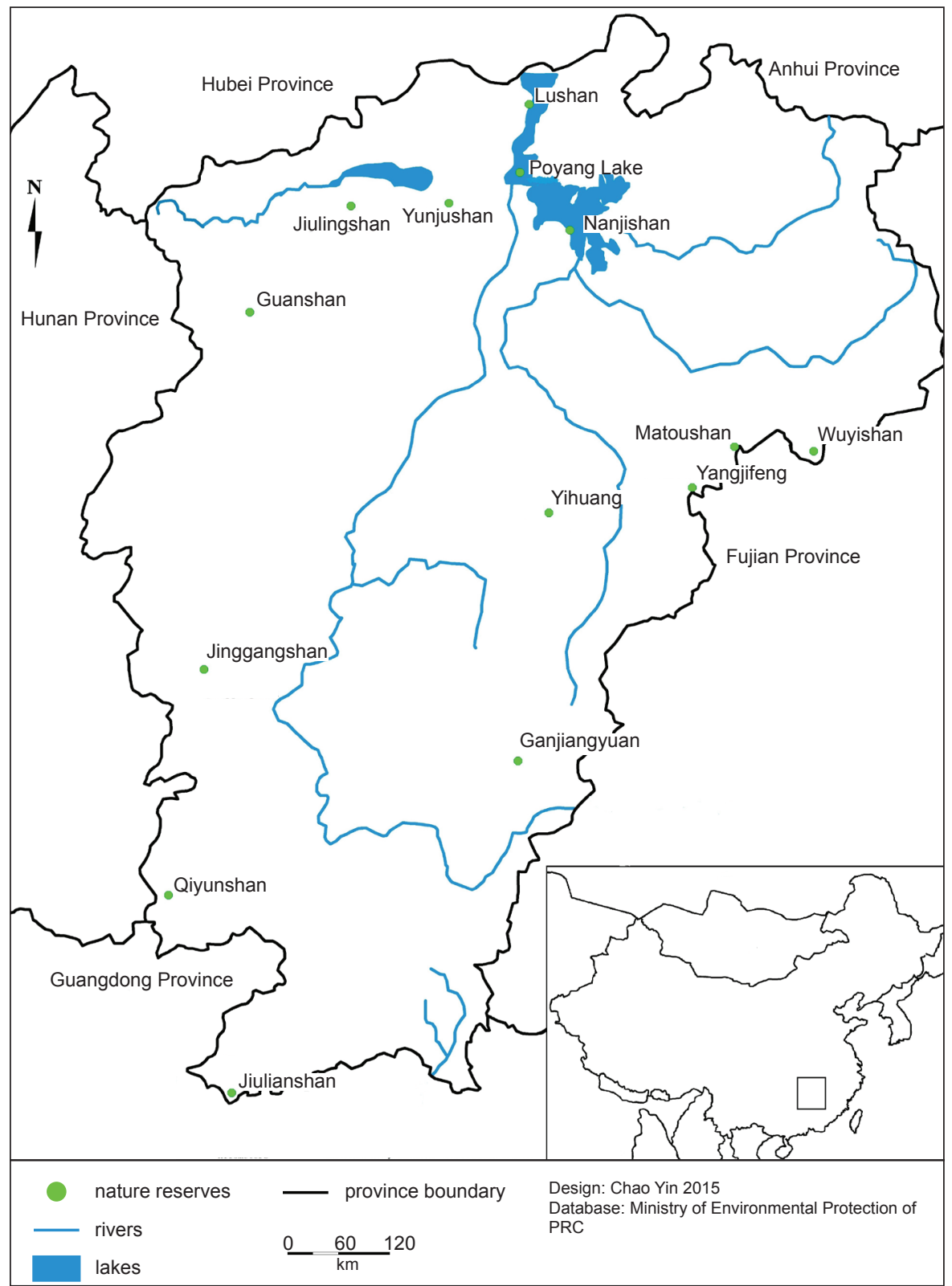

Figure 1 - Location of the 14 nature reserves in Jiangxi province, China.

G-index and F-index as G-F index, the values can be either positive or negative.

1. F-index, $\mathrm{D}_{\mathrm{F}}$ :

$$
\mathrm{D}_{\mathrm{F}}=-\sum_{\mathrm{k}=1}^{\mathrm{m}} \mathrm{D}_{\mathrm{F}_{\mathrm{k}}}=-\sum_{\mathrm{k}=1}^{\mathrm{m}} \sum_{\mathrm{i}=1}^{\mathrm{n}} \mathrm{p}_{\mathrm{i}} \ln \mathrm{p}_{\mathrm{i}}
$$

Where

$\mathrm{n}=$ the number of genera in the family $\mathrm{k}$, $\mathrm{p}_{\mathrm{i}}=\mathrm{S}_{\mathrm{k}} / \mathrm{S}_{\mathrm{k}}$,

$\mathrm{S}_{\mathrm{k}}$ the number of species in general,

$\mathrm{m}=$ the total number of families in the class.

2. G-index, $D_{G}$ :

$$
\mathrm{D}_{\mathrm{G}}=-\sum_{\mathrm{j}=1}^{\mathrm{P}} \mathrm{D}_{\mathrm{G}_{\mathrm{i}}}=-\sum_{\mathrm{j}=1}^{\mathrm{P}} \mathrm{q}_{\mathrm{j}} \ln \mathrm{q}_{\mathrm{j}}
$$

Where $\mathrm{q}_{\mathrm{i}}=\mathrm{S}_{\mathrm{i}} / \mathrm{S}$,

$S_{j}=$ the number of species in genus $j$,

$\mathrm{S}=$ the total number of species in the class,

$\mathrm{p}=$ the total number of genus in the class.

G-F index: $D_{G-F}=1-D_{G} / D_{F}$

In the early years, the technology of clustering analysis was always applied to mathematics. Now, with the development of computer technology, clustering analysis has begun to be used for studying the community ecology. Although clustering analysis was apply to the fish fauna distribution in the 1960s and popular in China in 1980s, now more and more people applied it to the fish fauna (Pan et al. 1985; Su 2009; Lv et al. 2014). With the like attracts like principle, the mutual relationship of fish species will be analysed after cat- 
Table 1 - Basic information of 14 nature reserves in Jiangxi Province, China.

\begin{tabular}{|c|c|c|c|c|}
\hline $\begin{array}{l}\text { Nature reserves } \\
\text { (NR) }\end{array}$ & $\begin{array}{l}\text { Area } \\
\left(\mathrm{km}^{2}\right)\end{array}$ & Location & Protecting object & Rank \\
\hline $\begin{array}{l}\text { Ganjiangyuan } \\
\text { NR (GJY) }\end{array}$ & 161 & $\begin{array}{r}116^{\circ} 03^{\prime}-116^{\circ} 20^{\prime} \mathrm{E} \\
25^{\circ} 52^{\prime}-26^{\circ} 06^{\prime} \mathrm{N} \\
\end{array}$ & Mid-subtropical broad-leaved evergreen forest & \multirow{12}{*}{ National } \\
\hline $\begin{array}{l}\text { Guanshan NR } \\
\text { (GN) }\end{array}$ & 115.01 & $\begin{array}{r}114^{\circ} 29^{\prime}-114^{\circ} 45^{\prime} \mathrm{E} \\
28^{\circ} 30^{\prime}-28^{\circ} 40^{\prime} \mathrm{N} \\
\end{array}$ & $\begin{array}{l}\text { Mid-subtropical broad-leaved evergreen forest, Syrmaticus ellioli and other } \\
\text { rare wild animals and plants }\end{array}$ & \\
\hline $\begin{array}{l}\text { Jinggangshan } \\
\text { NR (JGS) }\end{array}$ & 214.99 & $\begin{array}{r}113^{\circ} 34^{\prime}-118^{\circ} 28^{\prime} \mathrm{E} \\
24^{\circ} 29^{\prime}-30^{\circ} 04^{\prime} \mathrm{N} \\
\end{array}$ & Subtropical broad-leaved evergreen forest and rare animals & \\
\hline $\begin{array}{l}\text { Jiulianshan NR } \\
\text { (JLS) }\end{array}$ & 134.12 & $\begin{array}{r}114^{\circ} 27^{\prime}-114^{\circ} 29^{\prime} \mathrm{E} \\
24^{\circ} 31^{\prime}-24^{\circ} 39^{\prime} \mathrm{N} \\
\end{array}$ & Subtropical broad-leaved evergreen forest and wild animals and plants & \\
\hline $\begin{array}{l}\text { Jiulingshan NR } \\
\text { (JLS1) }\end{array}$ & 115.41 & $\begin{array}{r}115^{\circ} 03^{\prime}-115^{\circ} 24^{\prime} \mathrm{E} \\
28^{\circ} 49^{\prime}-29^{\circ} 03^{\prime} \mathrm{N} \\
\end{array}$ & Mid-subtropical broad-leaved evergreen forest, rare wild animals and plants & \\
\hline Lushan NR (LS) & 304.52 & $\begin{array}{r}115^{\circ} 52^{\prime}-116^{\circ} 08^{\prime} \mathrm{E} \\
29^{\circ} 26^{\prime}-29^{\circ} 41^{\prime} \mathrm{N} \\
\end{array}$ & The forest ecosystem of mid-subtropical areas & \\
\hline $\begin{array}{l}\text { Matoushan NR } \\
\text { (MTS) }\end{array}$ & 138.67 & $\begin{array}{r}117^{\circ} 09^{\prime}-119^{\circ} 9^{\prime} \mathrm{E} \\
27^{\circ} 40^{\prime}-27^{\circ} 53^{\prime} \mathrm{N}\end{array}$ & Subtropical broad-leaved evergreen forest and rare animals & \\
\hline $\begin{array}{l}\text { Nanjiishan NR } \\
\text { (NJS) }\end{array}$ & 333 & $\begin{array}{r}116^{\circ} 10^{\prime}-116^{\circ} 25^{\prime} \mathrm{E} \\
28^{\circ} 52^{\prime}-29^{\circ} 06^{\prime} \mathrm{N} \\
\end{array}$ & Swans and geese wetland habitat & \\
\hline $\begin{array}{l}\text { Poyang Lake NR } \\
\text { (PYL) }\end{array}$ & 224.00 & $\begin{array}{r}115^{\circ} 47^{\prime}-116^{\circ} 45^{\prime} \mathrm{E} \\
28^{\circ} 22^{\prime}-29^{\circ} 45^{\prime} \mathrm{N} \\
\end{array}$ & Rare birds and wetland habitat & \\
\hline $\begin{array}{l}\text { Qiyunshan NR } \\
\text { (QYS) }\end{array}$ & 171.05 & $\begin{array}{r}113^{\circ} 45^{\prime}-114^{\circ} 07^{\prime} \mathrm{E} \\
25^{\circ} 41^{\prime}-25^{\circ} 54^{\prime} \mathrm{N} \\
\end{array}$ & Fokienia hodginsii and other subtropical broad-leaved evergreen forests & \\
\hline $\begin{array}{l}\text { Wuyishan NR } \\
\text { (WYS) }\end{array}$ & 160.07 & $\begin{array}{r}117^{\circ} 39^{\prime}-117^{\circ} 55^{\prime} \mathrm{E} \\
27^{\circ} 48^{\prime}-28^{\circ} 00^{\prime} \mathrm{N} \\
\end{array}$ & Mid-subtropical broad-leaved evergreen forest and rare animals and plants & \\
\hline $\begin{array}{l}\text { Yangiifeng NR } \\
\text { (YJF) }\end{array}$ & 109.46 & $\begin{array}{r}117^{\circ} 11^{\prime}-117^{\circ} 28^{\prime} \mathrm{E} \\
27^{\circ} 51^{\prime}-28^{\circ} 2^{\prime} \mathrm{N} \\
\end{array}$ & $\begin{array}{l}\text { Amolops ricketti and giant spiny frog and other amphibians, subtropical } \\
\text { broad-leaved evergreen forest }\end{array}$ & \\
\hline Yihuang NR (YH) & 169.3 & $\begin{array}{r}116^{\circ} 7^{\prime}-116^{\circ} 10^{\prime} \mathrm{E} \\
27^{\circ} 9^{\prime}-27^{\circ} 20^{\prime} \mathrm{N}\end{array}$ & Chinese merganser & \multirow{2}{*}{ Provincial } \\
\hline $\begin{array}{l}\text { Yunjushan NR } \\
\text { (YJS) }\end{array}$ & 248.0 & $\begin{array}{r}115^{\circ} 33^{\prime}-117^{\circ} 37^{\prime} \mathrm{E} \\
29^{\circ} 02^{\prime}-29^{\circ} 07^{\prime} \mathrm{N} \\
\end{array}$ & The ecosystem of mid-subtropical broad-leaved evergreen forest & \\
\hline
\end{tabular}

egorizing the area. A similarity measure was conducted based on presence (1) or absence (0) of each species in each NR. All analyses were performed using PRIMER 5.0 software.

\section{Results}

\section{Fish composition}

146 freshwater fish species in the NRs were recorded, belonging to 7 orders, 26 families, accounting for $64.6 \%$ of the total species in Jiangxi Province (Huang \& Wu 2010a), see Table 2. The Cyprinidae family was the most dominant family with 103 species $(69.59 \%)$, followed by Siluriformes with 23 species $(15.5 \%)$ and Perciformes with 18 species (12.33\%). There was 1 species each in the orders of Beloniformes, Clupeiformes, Salmoniformes, Synbranchiformes. Opsariichthys bidens and Pseudorasbora prava were present in 13 nature reverses; Misgurnus anguillicaudatus, Zacco platypus, Acrossocheilus parallens and Carassius auratus were discovered in 12 nature reverses. However, about 59 fish species, such as Neosalanx taibuensis, Oreonectes platycephalus, appeared only in one of the 14 nature reverses ( $\mathrm{Ta}$ ble 3 , see at the end of the article).

\section{Fish diversity in the NRs of Jiangxi Province}

Data were obtained of F-index, G-index, G-F index data and the fish composition in the 14 nature reverses (Table 4). The table shows that the F-index, G-index and G-F index in Poyang Lake NR is the largest, 10.72, 3.746 and 0.651 respectively, followed by the indices of Nanjishan NR at 9.466, 3.707 and 0.608. The fish fauna in Poyang Lake NR and Nanjishan NR owes much to migrating fish in the Yangtze River. For the family level, Guanshan NR and Lushan NR have a lower value; and Ganjiangyuan NR scored the lowest value (2.022). Guanshan NR has the lowest value (1.946) at the genus level and only 7 species (belonging to 7 genera) captured there. The number of fish species decides the family and genus diversity level, the more fish gained, the larger the change in F-index, G-index and G-F index (Shi et al. 2010). The G-F index of Yangjifeng NR is -0.014 , that of Qiyunshan NR, Ganjiangyuan NR and Lushan NR is also negative $(-0.036,-0.0328$ and -0.363$)$. The main reason is that single genera and families make up a larger proportion in these four NRs. They failed to make a contribution to the F-index, which makes the $F<G$, leading to a negative G-F index value, and suggests that the diversity of family is greater than that of genus (Liu et al. 2004).

Relationship between species, area and latitude To analyse whether there is a similar discipline in the 14 NRs, we arranged Yihuang NR, Yunjushan NR, Yangjifeng NR, Guanshan NR, Jiulingshan NR, Jiulianshan NR, Matoushan NR, Wuyishan NR, Qiyunshan NR, Jinggangshan NR, Poyang Lake NR, Lushan NR and Nanjishan NR by area and obtained a scatter plot by comparing areas and species (Figure 2). The result shows that the fish species increased with the size of the area in the 14 NRs. However, there is 
Table 2 - The fish composition of 14 nature reserves.

\begin{tabular}{|l|r|r|r|}
\hline Nature reserves (NR) & Families & Genera & Species \\
\hline Ganjiangyuan NR & 8 & 15 & 16 \\
\hline Guanshan NR & 2 & 7 & 7 \\
\hline Jinggangshan NR & 12 & 31 & 38 \\
\hline Jiulianshan NR & 6 & 14 & 36 \\
\hline Jiulingshan NR & 12 & 33 & 39 \\
\hline Lushan NR & 8 & 17 & 17 \\
\hline Matoushan NR & 8 & 25 & 34 \\
\hline Naniishan NR & 14 & 43 & 58 \\
\hline Poyang Lake NR & 14 & 46 & 72 \\
\hline Qiyunshan NR & 9 & 19 & 20 \\
\hline Wuyishan NR & 9 & 31 & 36 \\
\hline Yangiifeng NR & 9 & 17 & 18 \\
\hline Yihuang NR & 7 & 22 & 25 \\
\hline Yunjushan NR & 5 & 15 & 17 \\
\hline
\end{tabular}

a larger difference in the last three points. The water area of Poyang Lake NR and Nanjishan NR occupies a larger proportion than that of the other $11 \mathrm{NRs}$, whereas the land area of Lushan NR is a main part. There is a close relationship between fish species and water area.

In descending order of latitude, the 14 NRs can be ordered as follows: Lushan NR, Poyang Lake NR, Jiulingshan NR, Yunjushan NR, Nanjishan NR, Guanshan NR, Wuyishan NR, Yangjifeng NR, Matoushan NR, Yihuang NR, Jinggangshan NR, Ganjiangyuan NR, Qiyunshan NR and Jiulianshan NR (Figure 3). The graph shows that species numbers increase with latitude. The anomaly was caused by the area and the location of sample points.

\section{Clustering analysis}

In the present study, the clustering shows that the fish fauna in the 14 NRs may be divided into five regions (Figure 4). The first region include Nanjishan NR and Poyang Lake NR: With Nanjishan NR located south of Poyang Lake NR, migratory fish account for $40 \%$ of all fish and the lakes taking in \& sending out waters of Nanjishan NR belong to Poyang Lake NR (Hu et al. 2011). The second and third groups are Guanshan NR and Matoushan NR. In the division of the world zoogeography, China belongs to the
Table 4 - Fish diversity indices in the 14 nature reserves of Jiangxi Province.

\begin{tabular}{|l|r|r|r|}
\hline Nature reserves (NR) & F-index & G-index & G-F index \\
\hline Ganiiangyuan NR & 2.022 & 2.686 & -0.328 \\
\hline Guanshan NR & 2.079 & 1.946 & 0.064 \\
\hline Jinggangshan NR & 4.009 & 3.355 & 0.163 \\
\hline Jiulianshan NR & 4.398 & 3.352 & 0.238 \\
\hline Jiulingshan NR & 5.362 & 3.379 & 0.370 \\
\hline Lushan NR & 2.079 & 2.833 & -0.363 \\
\hline Matoushan NR & 5.81 & 3.169 & 0.455 \\
\hline Naniishan NR & 9.466 & 3.707 & 0.608 \\
\hline Poyang Lake NR & 10.72 & 3.746 & 0.651 \\
\hline Qiyunshan NR & 2.715 & 2.813 & -0.036 \\
\hline Wuyishan NR & 6.75 & 3.391 & 0.498 \\
\hline Yangiifeng NR & 2.773 & 2.813 & -0.014 \\
\hline Yihuang NR & 3.429 & 2.997 & 0.126 \\
\hline Yunjushan NR & 2.773 & 2.588 & 0.067 \\
\hline
\end{tabular}

Oriental and the Palearctic regions. The fourth region includes Jiulianshan NR and Wuyishan NR, which belong to a mixture of the Oriental and Palaearctic regions. Jiulianshan NR lies at the source of Ganjiang River and Wuyishan NR lies upstream of Xinjiang River (Jiang \& Ji 1999). Lushan NR, Yunjushan NR, Yihuang NR, Yangjifeng NR, Ganjiangyuan NR, Qiyunshan NR, Jinggangshan NR and Jiulingshan NR belong to the fifth region. Yunjushan NR and Lushan NR are located in the Mufu Mountains. Yihuang NR, Yangjifeng NR and Ganjiangyuan NR belong to the Wuyi Mountains. Qiyunshan NR, Jinggangshan NR and Jiulingshan NR belong to Luoxiao Mountains and those points belong to the Oriental region, the southeast Asiatic subregion and the East China area (Liu \& Fang 2001; Liu \& Fu 2006; Huang et al. 2008; Huang \& Wu 2008; Li et al. 2008; Hu et al. 2009; Huang \& Wu 20010b; Guo et al. 2011; Zhou et al. 2013; Hu et al. 2014a, b; Yang et al. 2015).

\section{Discussion}

Contrary to the ecological diversity, the genus and family diversity can be evaluated by the catalogue of plants and animals and DG-F (Huang \& Liu 2011).

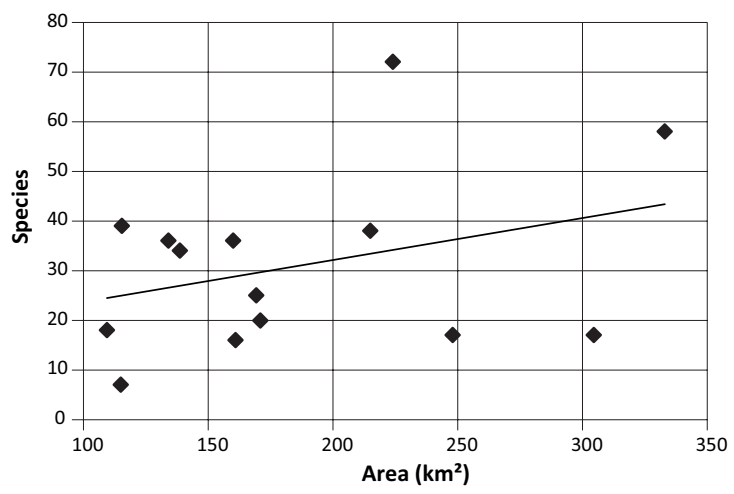

Figure 2 - The relation of fish species to area.

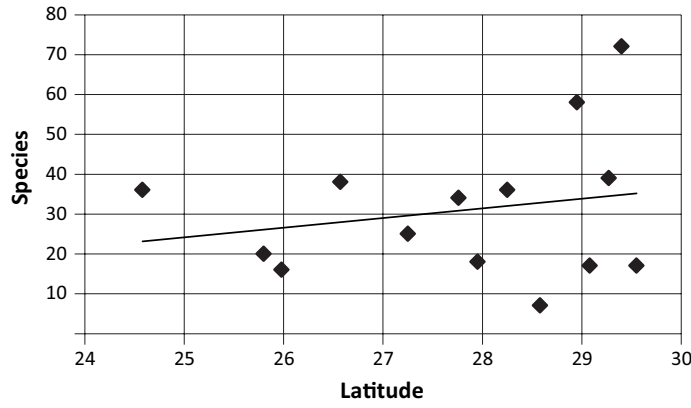

Figure 3 - The relation of fish species to latitude. 


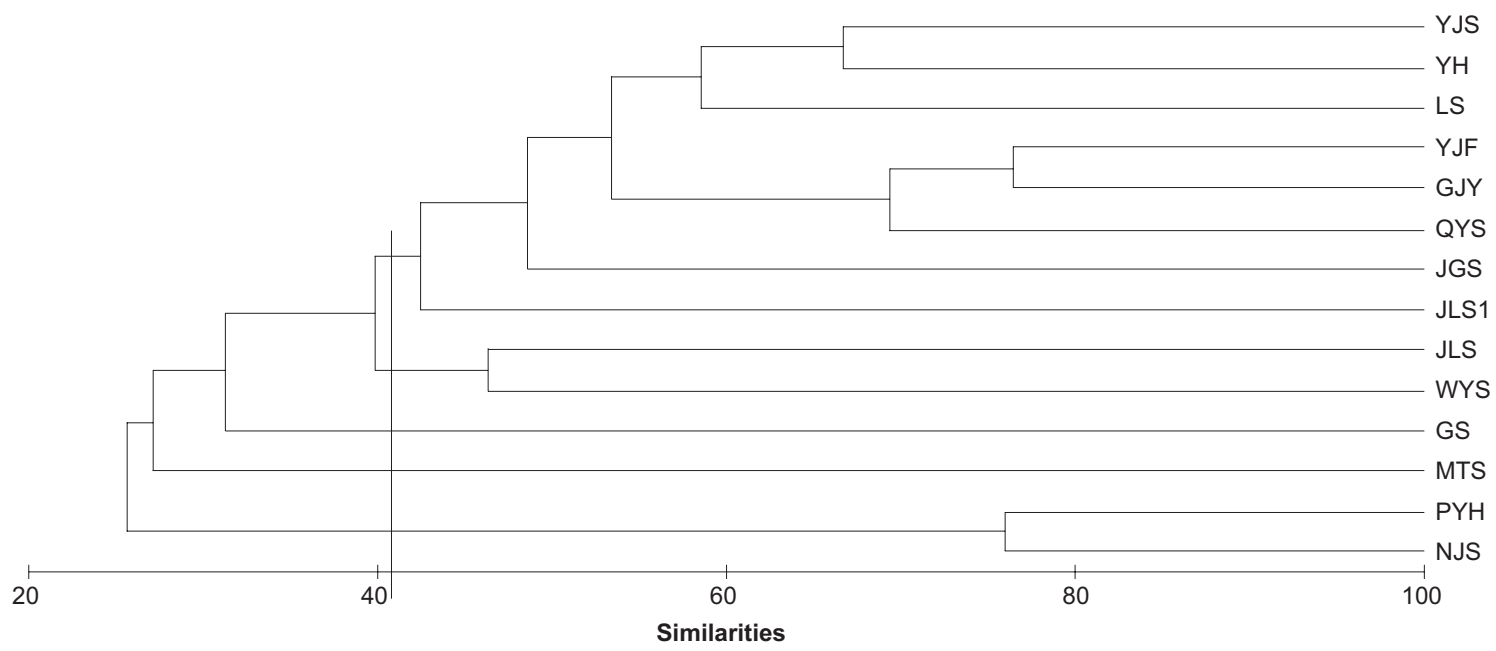

Figure 4 - The classification of the 14 nature reserves.

The study shows that the DG, DF and DG-F will score high with more fish species and distribute relatively evenly between genus and family (i.e. Nanjishan NR and Poyang Lake NR). The traditional biodiversity measure is embodied by the diversity of species, but the G-F index appears in the diversity of genus and family and reflects the overall level of diversity of any community (Zhang et al. 2002). The G-F index can be applied to study the biodiversity where there are no specific fish catches and a large working range.

Species-to-area is usually used to describe and evaluate the biodiversity (Amarasinghe \& Welcomme 2002; Yao et al. 2013). The relationship between species and area has been used in fish ecology in recent years whereas it was at first used to study plant diversity. The similar relationship is that the species richness changes with the increase of habitat area and declines with increasing latitude (Fu et al. 2003). Existing studies for vertebrates in Asia, America, Africa and Europe show that species will be reduced by $2.7 \%$ with each added degree of altitude (Zhang 1995). In this study a significant interaction between area and species can be found in a small area but a completely opposite conclusion in the relationship of latitude and species.

In the division of the world zoogeography, China belongs to the Oriential and Palearctic regions. With the distribution of fish species, the Oriental Region can be divided into a south-east Asiatic subregion and a south Asiatic subregion. The south-east Asiatic subregion is divided into an East China area and a South China area. The unique geographical position and river system have a great effect on fish species in Jiangxi Privince. In geographical terms, most NRs are located in the East China area of the south-east Asiatic subregion and in the Oriental Region and can be reduced to a group. The high similarity of species between Poyang Lake NRs and Nanjishan NRs is not only reflected in geographical positions and environment, but also embodied by the larger proportion of migratory fish and population and gene exchange. We attribute the main reason for such abnormality of two points to the fact that the water areas of Poyang Lake NR and Nanjishan NR are much larger than others and connected to the Yangtze River.

Worldwide, freshwater fish are the most diverse of all vertebrate groups and there may be some difference between reserve and non-reserve (Jang et al. 2003; Lawrence et al. 2015; Kwick \& Yeo 2015). Of a total of 229 freshwater fish species recorded throughout Jiangxi Province, about 146 species (63.7\%) are found in the 14 NRs. The fish species of Guanshan NR, Lushan NR and Jiulingshan NR (44 species) make up $46.8 \%$ of the total of those in the north-west of Jiangxi Province (94 species). Wuyishan NR, Matoushan NR and Yangjifeng NR have 65 species and account for $50.8 \%$ of the species in the north-east of Jiangxi Province (128 species). Nanjishan NR and Poyang Lake NR have 80 species and account for $58.8 \%$ of the Poyang Lake. The NRs contain various freshwater types, including stream fish (Opsariichthys bidens, Zacco platypus et al.) and migratory fish (Ctenopharyngodon idellus, Carassius auratus et al). Those data suggest that the NRs in Jiangxi Province are very important for freshwater fish diversity and conservation in Jiangxi Province, especially for the endemic Chinese species: 131 endemic species were collected from Poyang Lake Basin (Huang et al. 2013).

We compared the fish of the 14 NRs and divided them into 3 types. In most NRs with many mountains, high altitude and rapid streams (Yunjushan NR, Yangjifeng NR, Guanshan NR, Jiulingshan NR, Jiulianshan NR, Matoushan NR, Wuyishan NR, Qiyunshan NR, Jinggangshan NR, Lushan NR), Opsariichthys bidens, Zacco platypus and Acrossocheilus parallens are the most dominant species. In Nanjishan NR and Poyang Lake NR, with many lakes and swift-moving streams, Cyprinus carpio and Carassius auratus (dominant species) were found. Acanthorbodeus chankaensis and Abbottina rivularis (common species) were found in Yihuang NR and are preyed on by Chinese merganser. 


\section{Acknowledgements}

This work was supported by the National Natural Science Foundation of China (No. 51509042) and the Natural Science Foundation in Guangxi Province, China (No. 2014GXNSFBA118072), and the Project of High Level Innovation Team and Outstanding Scholar in Guangxi Colleges and Universities (No. 002401013001).

\section{References}

Amarasinghe, U.S. \& R.L. Welcomme 2002. An analysis of fish species richness in natural lakes. Environmental Biology of Fishes 65: 327-339.

Cai, D.S., X.G. Zhao, Y. Zhu, J. Zhou, J. Shi \& Y.Q. Han 2009. Investigation on fish resources and analysis of species diversity in Lijiang River. Journal of Guangxi Normal University 27(2): 130-136. [In Chinese]

Chen, H.C., M. Zhang, Z.G. Liu, Z. Zhang \& H.Y. Fang 2011. Assessment on freshwater ecosystem integrity and health in Gangjiang River basin through the fish IBI method. Resources and Environment in the Yangtre Basin 20(9): 1098-1107. [In Chinese]

David, J.L., E.R. Larson, C.A.R. Liermann, M.C. Mims, T.K. Pool \& J.D. Olden 2015. National parks as protected areas for U.S. freshwater fish diversity. Conservation Letters 4: 364-371.

Fu, C.Z., J.H. Wu, J.K. Chen, Q.H. Wu \& G.C. Lei 2003. Freshwater fish biodiversity in the Yangtze River basin of China: patterns, threats and Conservation. Biodiversity Conservation 12: 1649-1685.

Guo, Z.Z., D.L. Zou, R.L. Liu, Y.H. Pan, G.Y. Ye \& S.P. Liu 1964. The investigation on fish in Poyang Lake. Nanchang University 2: 121-130. [n Chinese]

Guo, Z.Z \& R.L. Liu 1995. The fishes of Jiangxi Province. Nanchang University 19(3): 222-232. [In Chinese]

Guo, S., Z.Q. Wu, M.L. Hu, M.L. Hu, H.M. Zhou \& Q. Li 2011. Preliminary Survey of Fish in Yangjifeng NR Jiangxi Province. Journal of Hydroecology 32(3): 142144. [In Chinese]

Huang, L.L, Z.Q. Wu, M.L. Hu, Q. Li, D.S. Zong, Z.Q. Wang \& W.Q. Zhao 2008. Species diversity of fish of Lushan NR in Jiangxi Provirice. Nanchang University 32(2): 161-164. [In Chinese]

Huang, L.L. \& Z.Q. Wu 2010a. Stream fish fauna composition and biogeographical analysis of the Northwestern, Jiangxi Province. Acta Hydrobiologica Sinica 34(2): 448-451. [In Chinese]

Huang, L.L. \& Z.Q. Wu 2010b. Fish resources of Jiulingshan NR in Jiangxi Province. Sichuan Journal of Zoology 29(2): 307-310. [In Chinese]

Huang, L.L., Z.Q. Wu \& J.H. Li 2013. Fish fauna, biogeography and conservation of freshwater fish in Poyang Lake Basin, China. Environmental Biology of Fishes 96: 1229-1243.
Huang, X.P. \& Y. Gong 2007. Fishery resources in Poyang Lake and its conservation. Jiangxi Fishery Science Technology 112(4): 2-6. [In Chinese]

Huang, Z.H. \& B. Liu 2011. G-F index of reptiles in Jiangxi Province. Journal of Jinggangshan University 32(3): 124-127. [In Chinese]

Hu, M.L, Z.Q. Wu, H.M. Zhou, A.F. Zhang, Y. Song \& C.Z. Zhang 2005. The fisheries characters and resource status of Nanjishan natural reserve in Poyang Lake. Resources and Environment in the Yangtze Basin 14 (5): 561-565. [In Chinese]

Hu, M.L., Z.Q. Wu \& Y.L. Liu 2009. The fish fauna of mountain streams in the Guanshan National NR, Jiangxi, China. Environment Biology Fishes 86: 23-27.

Hu, M.L, Z.Q. Wu \& Q. Li 2011. Preliminary research on fish species diversity of Ganjiangyuan NR in Jiangxi Province. Sichuan Journal of Zoology 33(3): 467-470. [In Chinese]

Hu, M.L., H.B. Xi, L. Hua, J.M. Zhang, H.M. Zhou, G. Ge \& Z.M. Ai 2014a. Preliminary investigations on fish resources of yihuang Mergus squamatus NR in Jiangxi Province. Nanchang University 38(5): 502-505. [In Chinese]

Hu, M.L., H.M. Zhou, S. Ouyang \& C. Chen 2014b. Freshwater fish species richness and conservation of mountain streams in the Jinggangshan National NR, China. eco.mont 6(2): 37-42.

Jang, H.M., M.C. Lucas \& G.J. Joo 2003 The fish fauna of mountain streams in South Korean national parks and its significance to conservation of regional freshwater fish biodiversity. Biological Conservation 114: 115-126.

Jiang, Y.J 1985. Preliminary analysis of fish fauna in Jiangxi. Jiangxi Fishery Science Technology 1985(2): 1-16. [In Chinese]

Jiang, Z.G. \& L.Q. Ji 1999. Avian-mammalian species diversity in nine representative sites in China. Chinese Biodiversity 7(3): 61-66. [In Chinese]

Kwik, T.B.J. \& D.C.J. Yeo 2015. Differences in fish assemblages in protected and non-protected freshwater streams in a tropical urbanized country. Hydrobiologia 2015: 1-14.

Lawrence, J.D., E.R. Larson, C.A.R. Liermann, M.C. Mims, T.K. Pool \& J.D. Olden 2015. National parks as protected areas for U.S. freshwater fish diversity. Conservation Letters 4: 364-371.

Li, Q., Z.Q. Wu, L.L. Huang, H.M. Chen \& J.H. Lu 2008. Fish resources of Qiyunshan NR Jiangxi, China. Acta Zootaxonomica Sinica 33(2): 324-329. [In Chinese]

Li, Y.M. \& X.B. Wu 2006. Avian diversity in Wuhu City in summer and winter. Chinese Journal of Applied Ecology 17(2): 269-274. [In Chinese]

Liu, X.Z. \& F.S. Fang (eds.) 2001. Science survey of the Wuyishan NR in Jiangxi. Beijing. [In Chinese]

Liu, X.Z., Z.Y. Xiao \& J.H. Ma (eds.) 2002. Scientific suvery and study on the forest ecosystem in Jiangxi Jiulianshan NR. Beijing. [In Chinese] 
Liu, X.Z. \& Q. Fu 2006. Scientific suvery and study of rare phytocoensium on the Matoushan NR Jiangxi Province. Beijing. [In Chinese]

Liu, H., H.Y. Shi \& L.Q. Zhang 2004. Analysis of water birds diversity in Mianyang Sichuan Province, China. Chinese Journal of Zoology 39(4): 85-89. In Chinese]

Liu, S.P. 1985. The investigation on fish resources of Fuhe Valley in Jiangxi. Nanchang University 1: 68-71. [In Chinese]

Lv, G.M., X.L. Huang, T. Li, F.Y.Z. Liu, Y.C. Cai, Z.Z. Ma \& Z. Huang 2014. Clustering analysis of karyotype resemblance-near coefficient of 20 Epinephelus species. Acta Agriculturae Zhejiangensis 26(6): 1484 1490. [In Chinese]

Ministry of Environmental Protection of The PRC. Writing a Research Paper. Available at: http http://sts.mep.gov.cn/zrbhq/zrbhq/201309/ t20130927_260955.htm (accessed: 15/05/13)

Pan, J.H., C.H. Liu \& H.M. Gu 1985. Chinese zoogeographical subregions of fishes: a tentative approach. Journal of South China Normal University 1: 8695. [In Chinese]

Su, X.H. 2009. Quantitative Hierarchical Clustering Sciaenoid Fishes (Sciaenidae) from Fujian, P. R. China. Journal of Biomathematics 24(4): 733-740. [In Chinese]

Shi, Y.R., Y.Z. Li, H. Ai, G.B. Chen, W.H. Lu, X.G. Li, N.N. Li, J. Yu, L.N. Dong, K. Cui \& D.F. Sun 2010. Fish taxonomic diversity of coral reef areas in Xisha Islands. Journal of Fisheries of China 34(11): 1753-1761. [In Chinese]

Wu, S.Y, H.Y. Xu, H.M. Zhong, Q.X. Zou \& Y. Qiu 2009. The preliminary analysis of the carrying capacity of water resources about Ganjiang River drainage basin. China Resources Comprehensive Utilization 27(2): 28-30. [In Chinese]

Yang, S.R., M.Z. Li, Q.G. Zhu, M.R. Wang \& H.Z. Liu 2015. Spatial and temporal variations of fish assemblages in Poyang Lake. Resources and Environment in the Yangtze Basin 24(1): 54-64. [In Chinese]

Yao, Y.Y., M. Yan \& R.C. Bi 2013. Relationships of plant community's species area curve with species diversity in Huoshan Mountain of Shanxi, China. Chinese Journal of Ecology 32(1): 39-44. [In Chinese]

Zhang, S.P., Z.W. Zhang, J.L. Xu, Q.H. Sun \& D.P. Liu 2002. The analysis of waterbird diversity in Tianjin. Biodiversity Science 10(3): 280-285. [In Chinese]
Zhang, E., H.Z. Liu \& C.C. He 1996. The study on fish fauna in Northeastern of Jiangxi province. Chinese Journal of Zoology 31(6): 3-12. [In Chinese]

Zhang, Z.B. 1995. Study on the relationship between species, area and latitude of vertebrates. Acta Ecologica Sinica 15(3): 305-311. [In Chinese]

Zhou, H.M., H.B. Xi, M.L. Hu, F.Li, S.D Yi \& A.F. Zhang 2013. Preliminary investigations on fish resources of Yunjushan NR in Jiangxi Province. Jiangxi Fishery Science Technology 136(4): 20-23. [In Chinese]

\section{Authors}

\section{Chao Yin ${ }^{1}$}

is a post-graduate student. His research focuses on environmental ecology. E-mail: yinchao31@163.com

\section{Liangliang Huang (contactor) ${ }^{1}$}

is associate professor. His resarch focuses on environmental ecology. E-mail: llhuang@glut.edu.cn

Li Xu ${ }^{1}$

is a researcher at the College of Environmental Science and Engineering. Her research focuses on ecological pollution processes.

E-mail: 1063164417@qq.com

\section{Jian Huang ${ }^{\text {T }}$}

is a postgraduate student. His research forcuses on ecological pollution processes.

E-mail: 527622075@qq.com

\section{Minghui Gao}

is a postgraduate student. His research forcuses on ecological pollution processes.

E-mail:1064419667@qq.com

${ }^{1}$ College of Environmental Science and Engineering, Guilin University of Technology, Guilin, Guangxi Zhuang Autonmous Region, 541004, People's Republic of China. 
Table 3 - The list of fish and distribution in the 14 natures reserves of Jiangxi Province, China. Abbreviations: GJY - Ganjiangyuan NR; GN - Guanshan NR; JGS - Jinggangshan NR; JLS - Jiulianshan NR; JLS 1 - Jiulingshan NR; LS - Lushan NR; MTS - Matoushan NR; NJS - Nanjishan NR; PYL - Poyang Lake NR; QYS - Qiyunshan NR; WYS - Wuyishan NR; YJF - Yangïfeng NR; YH - Yihuang NR; YJS - Yunjushan NR.

\begin{tabular}{|c|c|c|c|c|c|c|c|c|c|c|c|c|c|c|}
\hline Species & GJY & GN & JGS & JLS & JLS1 & LS & MTS & NJS & PYL & QYS & WYS & YJF & $\mathrm{YH}$ & YJS \\
\hline \multicolumn{15}{|l|}{ Beloniformes } \\
\hline \multicolumn{15}{|l|}{ 1) Hemiramphidae } \\
\hline Hyporhamphus intermedius & & & & & & & & & + & & & & & \\
\hline \multicolumn{15}{|l|}{ Clupeiformes } \\
\hline \multicolumn{15}{|l|}{ 2) Engraulidae } \\
\hline Coilia ectenes & & & & & & & & & + & & & & & \\
\hline \multicolumn{15}{|l|}{ Cypriniformes } \\
\hline \multicolumn{15}{|l|}{ 3) Cobitidae } \\
\hline \multicolumn{15}{|l|}{ (1) Botiinae } \\
\hline Cobitis taenia & & & & & & & + & & & & & & & \\
\hline Cobitis macrostigma & & & & & & & & & + & & & & & \\
\hline Cobitis sinensis & & & + & & & & & & + & & & & & \\
\hline Misgurnus anguillicaudatus & + & & + & + & & + & & & + & + & + & + & + & + \\
\hline Parabotia banarescui & & & & & & & & & + & & & & & \\
\hline Parabotia fasciata & & & & & & & & & + & & & & & \\
\hline Paramisgurnus dabryanus & & & & & & & & & + & & & & & \\
\hline \multicolumn{15}{|l|}{ (2) Noemacheilinae } \\
\hline Nemacheilus singhi & & & & + & & & & & & & & & & \\
\hline Oreonectes platycephalus & & & & & & & & & + & & & & & \\
\hline Schistura incerta & & & + & & & & & & & & & & & \\
\hline Schistura fasciolatus & & & & + & & & + & & + & + & & & & \\
\hline \multicolumn{15}{|l|}{ 4) Cyprinnidea } \\
\hline \multicolumn{15}{|l|}{ (1) Acheilognathinae } \\
\hline Acheilognathus macropterus & & & & & & & & & + & & & & & \\
\hline Acheilognathus chankaensis & & & + & & & & + & & + & & & & + & + \\
\hline Acheilognathus tabira & & & & & & & & & & & & & & \\
\hline Acheilognathus tonkinensis & & & & & & & & & + & & & & & \\
\hline Acheilognathus gracilis & & & & & & & & & + & & & & & \\
\hline Acheilognathus barbatulus & & & & & & & & & & & & & + & + \\
\hline Acheilognathus polylepis & & & & & & & + & & & & & & & \\
\hline Acheilognathus imberbis & & & & & & & & & + & & & & & \\
\hline Rhodeus sinensis & & & & & & & & & & & + & & & \\
\hline Rhodeus ocellatus & + & & & & & + & & & + & + & + & + & & \\
\hline Rhodeus lighti & & & & + & & & & & & & & & & \\
\hline (2) Barbinae & & & & & & & & & & & & & & \\
\hline Acrossocheilus fasciatus & & & & & & & + & & & & & & & \\
\hline Acrossocheilus parallens & + & + & + & + & & + & + & & & + & + & + & + & + \\
\hline Acrossocheilus hemispinus & & & & & & & + & & & & + & & & \\
\hline Spinibarbus caldwelli & & & & & & & + & & & & + & & & \\
\hline Varicorhinus lini & & & & + & & & & & & & & & & \\
\hline Varicorhiuns barbatulus & & + & + & + & & & + & & & + & + & + & & \\
\hline (3) Cultrinae & & & & & & & & & & & & & & \\
\hline Chanodichthys oxycephalus & & & & & & & & & + & & & & & \\
\hline Culter dabryyi & & & & & & & & & + & & & & & \\
\hline Culter alburnus & & & + & & & & & & + & & & & & \\
\hline Culter mongolicus & & & & & & & & & + & & & & & \\
\hline Cultrichthys erythropterus & & & & & & & & & + & & & & & \\
\hline Hemiculter leucisculus & & & + & & & & & & + & & + & & + & + \\
\hline Hemiculter bleekeri & & & & & & & & & + & & & & & \\
\hline Megalobrama mantschuricus & & & & & & & & & + & & & & & \\
\hline Megalobrama amblycephala & & & & & & & & & + & & + & & & \\
\hline Pseudolaubuca sinensis & & & & & & & & & + & & + & & & \\
\hline Pseudolaubuca engraulis & & & & & & & & & + & & & & & \\
\hline Parabramis pekinensis & & & & & & & & & + & & & & & \\
\hline Pseudohemiculter hainanensis & & & & & & & & & & & + & & & \\
\hline Pseudohemiculter dispar & & & & & & & + & & & & & & & \\
\hline Sinibrama macrops & & & & & & & + & & & & + & & & \\
\hline Toxabramis swinhonis & & & & & & & & & & & & & & \\
\hline (4) Cyprininae & & & & & & & & & & & & & & \\
\hline Cyprinus carpio & & & & + & & & & & + & + & + & & + & + \\
\hline Carassius auratus subsp & & & & + & & & & & & & & & & \\
\hline Carassius auratus & + & & + & + & & + & & & + & + & + & + & + & + \\
\hline
\end{tabular}




\begin{tabular}{|c|c|c|c|c|c|c|c|c|c|c|c|c|c|c|}
\hline Species & GJY & GN & JGS & JLS & JLS1 & LS & MTS & NJS & PYL & QYS & WYS & YJF & YH & YJS \\
\hline \multicolumn{15}{|l|}{ (5) Danioninae } \\
\hline Opsariichthys bidens & + & + & + & + & & + & + & & & + & + & + & + & + \\
\hline Zacco platypus & + & + & + & + & & + & + & & & + & & + & + & + \\
\hline \multicolumn{15}{|l|}{ (6) Gobioninae } \\
\hline \multicolumn{15}{|l|}{ Abbottina liaoningensis } \\
\hline Abbottina rivularis & & & + & & & + & & & + & & + & & + & + \\
\hline Coreius heterodon & & & & & & & & & + & & & & & \\
\hline Gnathopogon taeniellus & & & & + & & & & & & & & & & \\
\hline Gnathopogon imberbis & + & & & & & + & & & & & & + & + & \\
\hline Hemibarbus maculatus & & + & & + & & + & & & + & & + & & & \\
\hline \multicolumn{15}{|l|}{ Hemibarbus umbrifer } \\
\hline Hemibarbus laneo & & & + & + & & & & & & & + & & & \\
\hline Huigobio chenhsienensis & & & & & & & + & & & & & & & \\
\hline Huigobio chinssuensis & & & & & & & + & & & & & & & \\
\hline Microphysogobio kiatingensis & & & + & & & & & & & & + & & & \\
\hline Microphysogobio fukiensis & & & + & & & & & & & & & & & \\
\hline Paracanthobrama guichenoti & & & & & & & & & + & & & & & \\
\hline Pseudorasbora parva & + & + & + & + & & + & & & + & + & + & + & + & + \\
\hline Pseudogobio guilinensis & & & & + & & & & & & & & & & \\
\hline Pseudogobio vaillanti & & & & & & & + & & & & + & & + & \\
\hline Rhinogobio typus & & & + & & & & & & + & & & & + & \\
\hline Sarcocheilichthys sinensis & & & & & & & & & + & & & & & \\
\hline Sarcocheilichthys kiangsiensis & & & + & & & & & & & & & & + & \\
\hline Sarcocheilichthys parvus & & & + & & & & + & & + & & & & + & \\
\hline \multicolumn{15}{|l|}{ Sarcocheilichthys nigripinnis } \\
\hline Saurogobio gracilicaudatus & & & & & & & + & & & & & & & \\
\hline Saurogobio gymnocheilus & & & & & & & & & + & & & & & \\
\hline Saurogobio dumerili & & & & & & & & & + & & & & & \\
\hline Saurogobio dabryi & & & + & & & & & & + & & & & + & \\
\hline Squalidus argentatus & & & + & & & & & & + & & & & + & \\
\hline Squalidus wolterstorffi & & & & & & & & & + & & & & & \\
\hline \multicolumn{15}{|l|}{ Squalidus atromaculatus } \\
\hline \multicolumn{15}{|l|}{ (7) Gobiobotinae } \\
\hline Gobiobotia tungi & & & & + & & & & & & & & & & \\
\hline Gobiobotia filifer & & & & & & & & & + & & & & & \\
\hline \multicolumn{15}{|l|}{ (8) Hypophthalmichthyinae } \\
\hline Aristichthys nobilis & & & & & & & & & + & & + & & & \\
\hline Hypophthalmichthys molitrix & & & & & & & & & + & & + & & & \\
\hline (9) Leuciscinae & & & & & & & & & & & & & & \\
\hline Ctenopharynodon idellus & & & & + & & & & & + & + & + & & & + \\
\hline Elopichthys bambusa & & & & & & & & & + & & & & & \\
\hline Mylopharyngodon piceus & & & & & & & & & + & & + & & & \\
\hline Rhynchocypris lagowskii & & & & & & & + & & & & & & & \\
\hline Rhynchocypris oxycephalus & & & & & & + & & & & & & & & + \\
\hline Squaliobarbus curriculus & & & & & & & & & + & & & & & \\
\hline (10) Xenocyprinae & & & & & & & & & & & & & & \\
\hline Distoechodon tumirostris & & & & & & & & & & & + & & & \\
\hline Pseudobrama simoni & & & & & & & & & + & & & & & \\
\hline Xenocypris davidi & & & & & & & & & + & & + & & & \\
\hline Xenocypris argentea & & & & & & & & & + & & & & & \\
\hline 5) Homalopteridae & & & & & & & & & & & & & & \\
\hline (1) Gastromyzoninae & & & & & & & & & & & & & & \\
\hline Crossostoma stimata & + & & & & & & & & & & & & & \\
\hline Liniparhomaloptera disparis & & & & & & & + & & & & & & & \\
\hline Pseudogastromyzon changtingensis & & & & & & & & & & + & & & & \\
\hline Pseudogastromyzon fasciatus & & & & & & & + & & & & & & & \\
\hline Preaformosania lineota & & & & + & & & & & & & & & & \\
\hline Pseudogastromyzon changtingensistungpeiensis & & & + & + & & & & & & & + & & & \\
\hline Vanmanenia pingchowensis & + & & + & & & & & & & + & & + & & \\
\hline Vanmanenia stenosoma & & + & + & & & & + & & & + & & & & \\
\hline Vanmanenia xinyiensis & + & & & & & & & & & & & & & \\
\hline Vanmanenia hainanensis & & & & + & & & & & & & & & & \\
\hline Vanmanenia caldwelli & & & + & & & & & & & & & & & \\
\hline Perciformes & & & & & & & & & & & & & & \\
\hline 6) Belontiidae & & & & & & & & & & & & & & \\
\hline Macropodus opercularis & & & & + & & & & & & & & & & \\
\hline Macropodus chinensis & + & & & + & & & & & & + & & + & + & \\
\hline
\end{tabular}




\begin{tabular}{|c|c|c|c|c|c|c|c|c|c|c|c|c|c|c|}
\hline Species & GJY & GN & JGS & JLS & JLS1 & LS & MTS & NJS & PYL & QYS & WYS & YJF & $\mathrm{YH}$ & YJS \\
\hline \multicolumn{15}{|l|}{ 7) Channidae } \\
\hline Channa maculate & & & & + & & & & & & & & & & \\
\hline Channa argus & & & & & & + & & & + & & & & & \\
\hline Channa asiatica & & & & + & & & & & & & & & & \\
\hline \multicolumn{15}{|l|}{ 8) Eleotridae } \\
\hline Odontobutis obscurus & & & + & & & & & & + & & & & & \\
\hline \multicolumn{15}{|l|}{ 9) Gobiidae } \\
\hline Rhinogobius giurinus & & & + & + & & + & + & & + & & + & + & + & + \\
\hline \multicolumn{15}{|l|}{ Rhinogobius duospilus } \\
\hline Rhinogobius cliffordpopei & + & & + & & & & + & & & + & & + & + & + \\
\hline \multicolumn{15}{|l|}{ 10) Mastacembelidae } \\
\hline Mastacembelus armatus & & & & + & & & & & & & & & & \\
\hline Mastacembelus sinensis & & & + & & & & & & + & & & & & \\
\hline \multicolumn{15}{|l|}{ 11) Odontobutidae } \\
\hline Micropercops cinctus & & & & + & & & + & & + & & & & & \\
\hline Odontobutis sinensis & & & & & & & & & & & & & + & \\
\hline \multicolumn{15}{|l|}{ 12) Serranidae } \\
\hline Coreosiniperca roulei & & & & & & & & & + & & & & & \\
\hline Siniperca chuatsi & & & + & & & & & & + & & + & & & \\
\hline Siniperca scherzeri & & & & & & & & & + & & & & & \\
\hline Siniperca undulata & & & & + & & & & & & & & & & \\
\hline Siniperca kneri & & & & & & & & & + & & & & & \\
\hline \multicolumn{15}{|l|}{ Salmoniformes } \\
\hline \multicolumn{15}{|l|}{ 13) Salangidae } \\
\hline Neosalanx taihuensis & & & & & & & & & + & & & & & \\
\hline \multicolumn{15}{|l|}{ Siluriformes } \\
\hline \multicolumn{15}{|l|}{ 14) Amblycipitidae } \\
\hline Liobagrus anguillicauda & & & + & & & + & & & & & & + & & \\
\hline Liobagrus nigricauda & & & & & & & & & + & & & & & \\
\hline Liobagrus marginatus & & & & & & & + & & & & & & & \\
\hline \multicolumn{15}{|l|}{ 15) Bagridae } \\
\hline Mystus macropterus & & & + & & & & + & & & & + & & & \\
\hline Leiocassis crassilabris & & & & & & & & & + & & & & & \\
\hline Leiocassis truncatus & & & & & & & + & & & & & & & \\
\hline Pelteobagrus fulvidraco & & & + & & & + & + & & + & & & + & + & \\
\hline Pelteobagrus eupogon & & & & & & & & & + & & & & + & \\
\hline Pelteobagrus nitidus & & & & & & & & & + & & & & & \\
\hline Pelteobagrus vachelli & & & & & & & & & + & & & & & \\
\hline Pelteobagrus ussuriensis & & & + & & & & + & & & & & & & \\
\hline Pseudobagrus tenuifurcatus & & & & & & & + & & & & & & & \\
\hline Pseudobagrus pratti & & & + & & & & + & & & & & & & \\
\hline Pseudobagrus truncatus & & & & + & & & + & & & & & & & \\
\hline Pseudobagrus ondon & + & & + & & & & & & & & & + & & \\
\hline \multicolumn{15}{|l|}{ Pseudobagrus tenuis } \\
\hline Pseudobagrus emarginatus & & & & & & & & & & & & & & \\
\hline 16) Clariidae & & & & & & & & & & & & & & \\
\hline Clarias fuscus & + & & & + & & & + & & & + & + & + & & \\
\hline 17) Sisoridae & & & & & & & & & & & & & & \\
\hline Glyptothorax sinense & & & + & & & & & & & & + & & & \\
\hline Glyptothorax fokiensis & & & & + & & & & & & & + & & & \\
\hline 18) Siluridae & & & & & & & & & & & & & & \\
\hline Silurus cochinchinensis & & & & + & & & & & & & & & & \\
\hline Silurus asotus Linnaeus & & & + & + & & + & & & + & + & + & + & & + \\
\hline Silurus meridionalis & & & & & & & & & + & & & & & \\
\hline Synbranchiformes & & & & & & & & & & & & & & \\
\hline 19) Synbranchidae & & & & & & & & & & & & & & \\
\hline Monopterus albus & + & & + & + & & + & & & + & + & + & & + & + \\
\hline
\end{tabular}

